\title{
THE INVESTIGATION OF POLYLACTIC ACID BASED NATURAL FIBER REINFORCED BIOCOMPOSITES FOR AUTOMOTIVE APPLICATIONS
}

\author{
Süleyman Sinan ÖZTÜRK*1 \\ ${ }^{*}$ R\&D Department of TOFAŞ TÜRK OTOMOBIL FABRIKKASI AŞ, 16110 Bursa, TURKEY
}

\begin{abstract}
An automotive application with renewable sources as environmentally sustainable solution has been studied for weight reduction. Hemp as non-woven natural fiber (NNF) and Polylactic acid (PLA) non-woven fibers has been used to form continuous mat by needle-punch method. This biobased mat structure was then hot formed to achieve good mechanical properties. The composition of the fiber was 50:50 / NNF:PLA and the density of the final sheet was $1300 \mathrm{gr} / \mathrm{m}^{2}$, the final thickness of the biocomposite after themoforming was $2.2 \mathrm{~mm}$ with 2.1 GPa Flexural Modulus and $17 \mathrm{MPa}$ Tensile Strength and 2.3\% elongation at break. In this study, the mechanical performance of this biocomposite structure under water immersion, $40^{\circ} \mathrm{C}$ and $80^{\circ} \mathrm{C}$ was studied. The charpy impact strength was found $21 \mathrm{~kJ} / \mathrm{m}^{2}$. The major outcome of this study is replacing conventional reinforcement materials with renewable sources which offers lower weight and tolerable mechanical strengths.
\end{abstract}

Keywords: PLA polymer, Hemp natural fiber, biocomposite, automotive application

\section{DOĞAL ELYAF TAKVIYYELİ POLILAKTIKK ASITT BIYYOKOMPOZIT YAPILARIN ARAÇ UYGULAMALARI İÇIN İNCELENMESI}

\section{Özet}

Araç hafifletme projesine yönelik çevresel sürdürülebilirlik çözümleri kapsamında doğal kaynakların kullanılması çalışma yapılmıştır. Kenevir doğal fiberleri ve Polilaktik Asit (PLA) fiberleri, iğneleme yöntemi ile sürekli matlar haline getirilmiştir. Bu kompozit yapıya 1sıl işlem ile form edilerek iyi mekanik özellikler kazandırılmıştır. Kompozisyondaki fiber oranı 50:50 / Doğal Elyaf:PLA ve yoğunluk $1300 \mathrm{gr} / \mathrm{m}^{2}$, nihai kalınlık ise $2.2 \mathrm{~mm}$ olarak hazırlanmıştır. Elde edilen kompozit yapı 2.1 GPa Eğilme Modulü ve $17 \mathrm{MPa}$ Kopma Dayanımı ve 2.3\% kopma uzaması değerlerine ulaşmıştır. Bu çalışmada, biyokompozit yapının su emdirildikten sonra, $40^{\circ} \mathrm{C}$ ve $80^{\circ} \mathrm{C}$ yaşlandırma sonrası mekanik özelliklerinin değişimi incelenmiştir. Charpy Darbe Dayanımı $21 \mathrm{~kJ} / \mathrm{m}^{2}$ olduğu bulunmuştur. Bu çalışmada, konvensiyonel olarak üretilebilecek fiber katkılarla güçlendirilmiş, sürdürülebilir kaynaklarla üretilmiş hafifletilmiş kompozit yapı çalışılmıştır ve araç projelerinde kullanılabilir mekanik özellikleri sağlanmıştır.

Anahtar Kelimeler: PLA polimer, Kenevir doğal elyaf, biokompozit, otomotiv uygulamaları

* Corresponding author: suleymansinan.ozturk@ tofas.com.tr, https://orcid.org/0000-0002-6011-5673 
Araştırma

DOI: $10.34186 /$ klujes. 626590
Öztürk/Kırklareli University Journal of Engineering and Science 6-1(2020) 21-31

Geliş Tarihi:30.09.2019

\section{INTRODUCTION}

As the new regulations are decreasing the emission limits of the greenhouse gases year by year, automotive industry focuses on weight reduction as the weight of the car is one of the parameter for the energy consumption. Most of the automotive companies keep working on composite structures among with lower weight high strength metal solutions. Due to potential low density of carbon fiber and natural fiber, such fiber reinforced composite solutions result into weight reduction [1-2]. Natural fibers have been vastly studied since they are abundant, sustainable, environmental friendly and cheaper than carbon fibers [3] The bast fibers such as kenaf, hemp and flax can be used as reinforcement to polymeric matrix. The randomly oriented fibers are more easily formed and eliminate the distortion when compared with the continuous fibers [4]. The natural fibers are hydrophilic and adhesion to the hydrophobic polymer matrix like polypropylene can be enhanced by using high melt flow polymers and by heating during process. Heating to high temperature can degrade natural fibers and lose the elasticity of the structure [5]. The adhesion problem of cellulose based fibers with hydrophobic polymers was improved by coupling agents like maleic anhydride or surface modification of the fiber surface [6-7].

A greener solution to form biocomposite is to use biodegradable polyester polymer matrix such as PLA. Natural fiber: PLA composites have been studied with different manufacturing techniques like sheet forming, extrusion and compression to understand the mechanical properties $[8,9]$ The drawback of such biocomposites is the sensitivity of the fiber to humidity and heat which limits the use in automotive components like door panels, parcel shelves and trim parts of dashboard. The automotive application of natural fiber composites goes back to 1940s when Henry Ford first used hemp composite solution. Current composite solutions are around $1500 \mathrm{gr} / \mathrm{m} 2$ and $1000 \mathrm{gr} / \mathrm{m} 2$ can be achieved with thermoset process.

The aim of this study is to understand the mechanical properties of 50\%:50\% hemp fiber reinforced PLA fibers needle-punched to obtain mat which is then heated and compression molded to form a sheet. The effect of temperature on mechanical behaviour of the sheet was studied. The effect of humidity and change of the mechanical properties when exposed to water was studied. A further characterization technique such as TGA and DSC was performed to observe thermal behaviour of the composite structure. The adhesion of PLA to natural fiber was controlled by stereomicroscopy to understand the structure of the composite. 
Araştırma

DOI: $10.34186 /$ klujes. 626590
Öztürk/Kırklareli University Journal of Engineering and Science 6-1(2020) 21-31

Geliş Tarihi:30.09.2019

Kabul Tarihi:30.06.2020

\section{MATERIAL AND METHODS}

Hemp used in this study was from industrial straw of Cannabis sativa defibering followed by mechanical refining. Average length of the fibers were $117 \pm 8 \mu \mathrm{m}$ with average diameter of $141 \pm 47 \mu \mathrm{m}$. The average length of the PLA fibers were between $33 \mathrm{~mm}$ to $165 \mathrm{~mm}$, the tenacity of the fibers were $1.8 \mathrm{cN} / \mathrm{dtex} \pm 25 \%$.

The natural fibers and PLA fibers were needle-punched as $50: 50$ to produce $1300 \mathrm{gr} / \mathrm{m} 2$ of mat. The mat is then hot-pressed with roller at $195^{\circ} \mathrm{C}$ for 45 seconds. The thermoformed sheet is then machine cut to produce specimen for mechanical tests.

The visual control was performed with Leica DMi8 stereomicroscope. The DSC curve was observed with Netzsch 204 F1 and TGA graph was collected with Mettler Toledo TGA/DSC 1 Star. The mechanical tests were done with Zwick $10 \mathrm{kN}$ Universal Testing Machine. The charpy impact strength test was performed with Instron Charpy Impact Analyzer.

\section{RESULTS AND DISCUSSION}

\subsection{Density of Composite sheets}

The weight/area of the sheet was calculated by measuring the weight of a $100 \mathrm{~mm} \times 100 \mathrm{~mm} \times 2.2 \mathrm{~mm}$ sample and dividing by the total area. The weight/volume of the sheet was calculated by measuring the weight and volume of the sheet.

Table 1. The density of the sheet

\begin{tabular}{|c|c|c|}
\hline Sheet Sample & Weight/Area gr/m² & Weight/Volume gr/cm \\
\hline 1 & 1392 & 0.54 \\
\hline 2 & 1369 & 0.58 \\
\hline 3 & 1324 & 0.56 \\
\hline Average & 1362 & 0.56 \\
\hline
\end{tabular}

\subsection{DSC of Composite sheets}

The DSC curve was collected first heating from $30^{\circ} \mathrm{C}$ to $220^{\circ} \mathrm{C}$ with $10 \mathrm{~K} / \mathrm{min}$ heating rate and kept isothermal for 5 minutes (Figure 1). The cooling rate was 10K/min with 3 minutes isothermal and the second heating was to $220^{\circ} \mathrm{C}$ with $10 \mathrm{~K} / \mathrm{min}$ heating rate. The nitrogen atmosphere with $70 \mathrm{~mL} / \mathrm{min}$ purge flow and $20 \mathrm{~mL} / \mathrm{min}$ gas flow was used. The melting peak of 
Araştırma

DOI: $10.34186 /$ klujes. 626590
Öztürk/Kırklareli University Journal of Engineering and Science 6-1(2020) 21-31

Geliş Tarihi:30.09.2019

PLA was calculated from second heating curve as $166.8^{\circ} \mathrm{C}$ with $22.3 \mathrm{j} / \mathrm{g}$ entalpy of fusion. With the equation 1 , the crystallinity of the polymer $\mathrm{X}_{\mathrm{c}}(\%)$ can be calculated where $\Delta \mathrm{H}_{\mathrm{m}}$ is the entalphy of fusion $(\mathrm{J} / \mathrm{g})$, and $\Delta H_{m}^{0}$ is the standard enthalpy of PLA for $100 \%$ crystallinity, equal to $93.7 \mathrm{~J} / \mathrm{g}$. The crystallinity of the PLA polymer is $6.7 \%$.

$$
X_{c}(\%)=\frac{\Delta H_{m}}{\Delta H_{m}^{0}}
$$

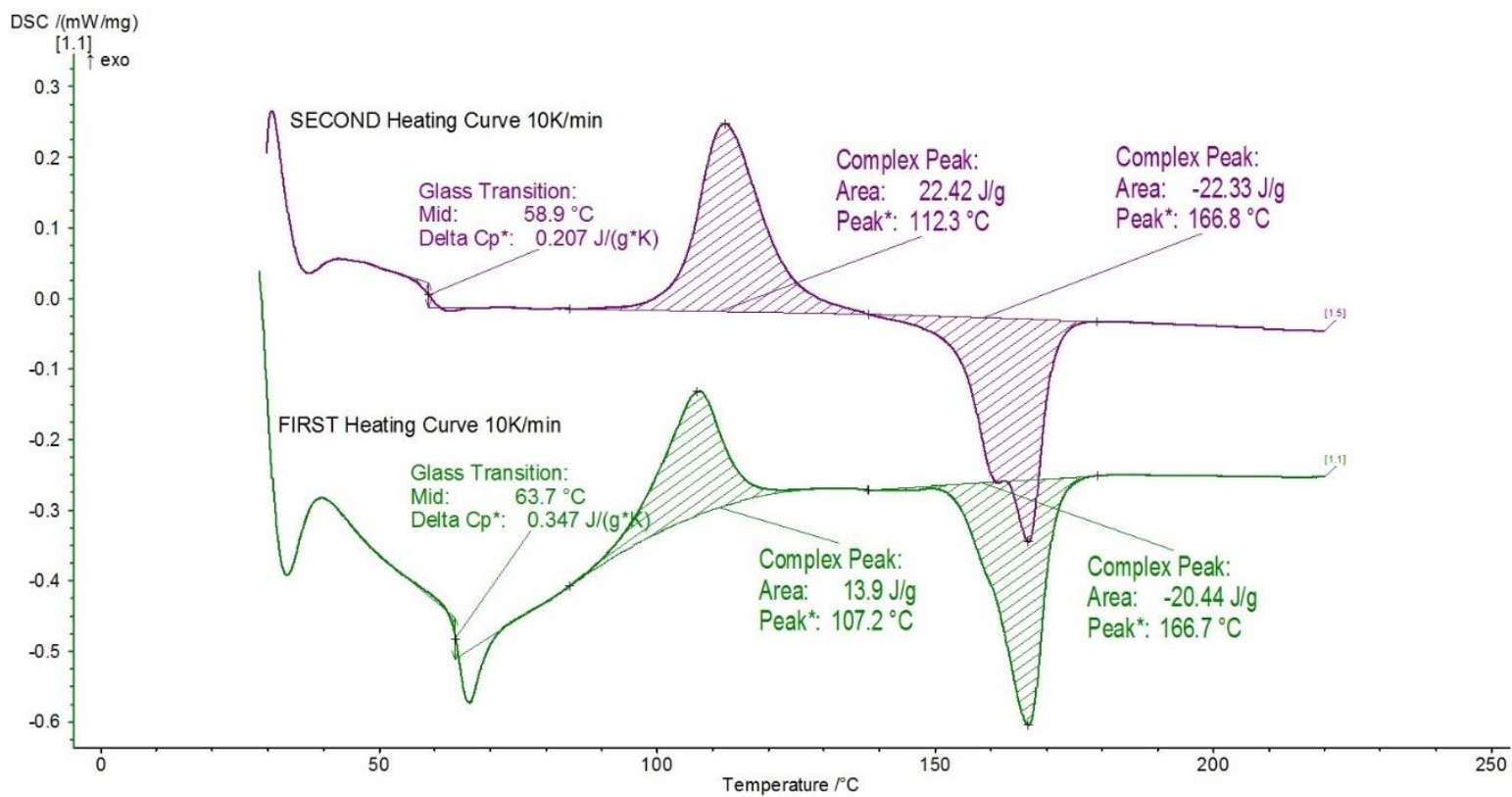

Figure 1. DSC curves of the composite structure, first heating curve (green), second heating curve (purple)

The glass transition of the PLA from first heating curve is $63.7^{\circ} \mathrm{C}$. The glass transition temperature of the polymer is important for defining the working temperature of the composite. In this case, the composite sheet will be further thermoformed to finished product where the composite will be glassy before $58.9^{\circ} \mathrm{C}$ and softening will be affecting the mechanical properties.

\subsection{TGA of Composite sheets}

The TGA was measured to characterize the thermal stability of the composite structure (Figure 2). The heating curve was $20 \mathrm{~K} / \mathrm{min}$ from $30{ }^{\circ} \mathrm{C}$ to $600{ }^{\circ} \mathrm{C}$ under nitrogen atmosphere and isothermal for 5 minutes. Then heating to $800{ }^{\circ} \mathrm{C}$ with $20 \mathrm{~K} / \mathrm{min}$ under oxygen atmosphere. The flow of the gas was constant at $60 \mathrm{~mL} / \mathrm{min}$. 
Araştırma

DOI: $10.34186 /$ klujes. 626590
Öztürk/Kırklareli University Journal of Engineering and Science 6-1(2020) 21-31 Geliş Tarihi:30.09.2019

Kabul Tarihi:30.06.2020

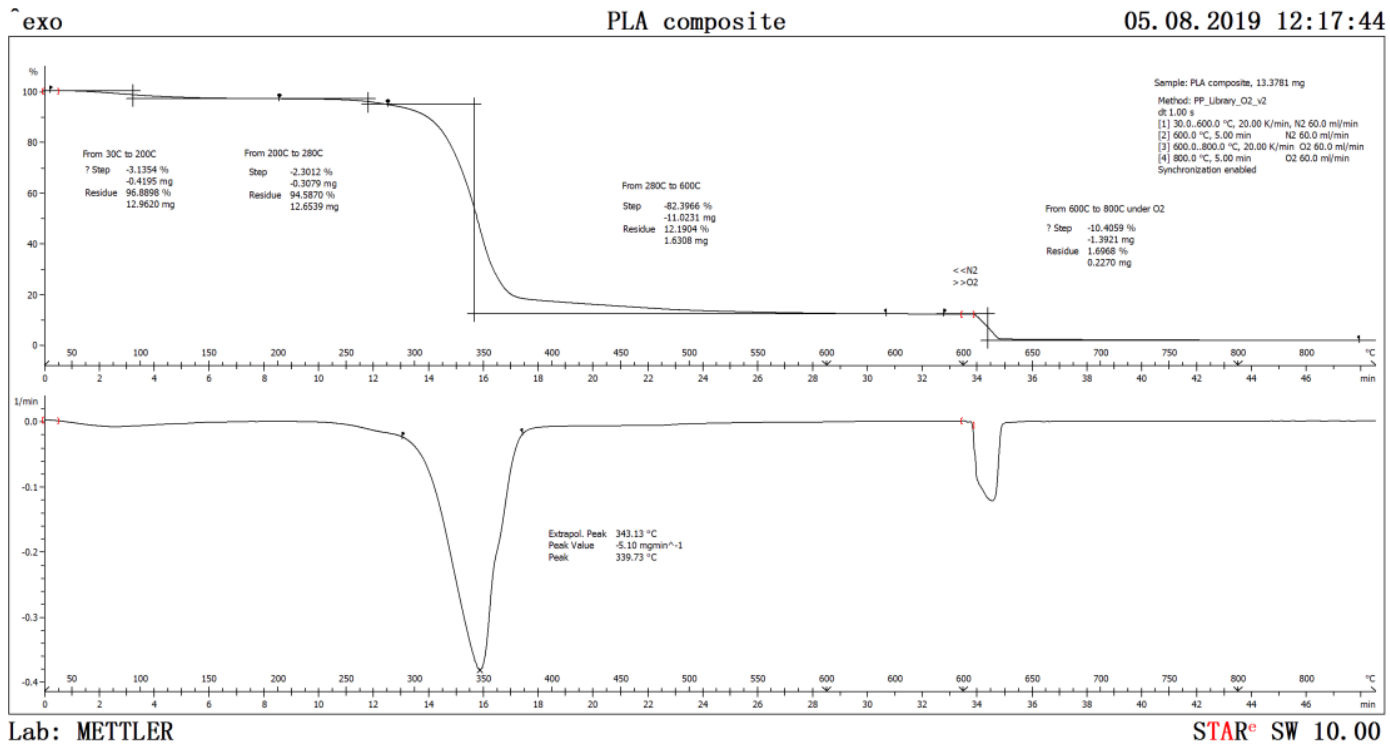

Figure 2. TGA graph of the composite structure (above), DTGA of the composite (below)

In the TGA graph, the weight loss of the composite was $82 \%$ where from DTGA the decomposition peak was observed at $339.7^{\circ} \mathrm{C}$. The residual weight of the composite was $1.7 \%$ which is mainly due to flame retardant used in the PLA fiber. The weight loss in the first step is due to water loss which was $3.1 \%$.

\subsection{FT-IR spectrum of Composite sheet}

The FT-IR spectrum was collected with Bruker Tensor II between 400-4000 cm${ }^{-1}$ with 24 scans with $4 \mathrm{~cm}^{-1}$ resolution (Figure 3 ).
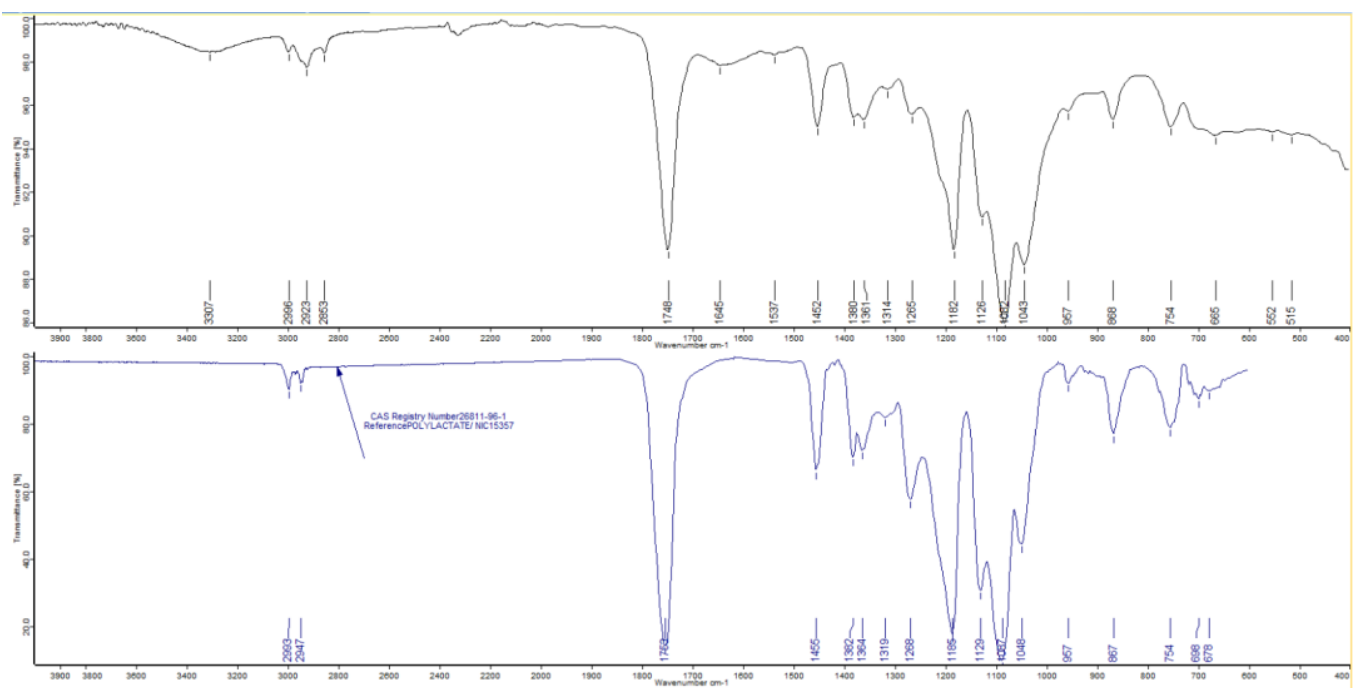

Figure 3. FT-IR spectrum of the composite structure (above), PLA from reference library CAS 26811-96(below) 
Araştırma

DOI: $10.34186 /$ klujes. 626590
Öztürk/Kırklareli University Journal of Engineering and Science 6-1(2020) 21-31

Geliş Tarihi:30.09.2019

The $-\mathrm{OH}$ stretching band was observed between $3200-3500 \mathrm{~cm}^{-1}$, the $\mathrm{C}=\mathrm{O}$ stretching was at $1748 \mathrm{~cm}^{-1}$, and C-O-C stretching was observed at $1182 \mathrm{~cm}^{-1}$ and $1082 \mathrm{~cm}^{-1}$. The typical PLA spectrum was confirmed with reference library CAS 26811-96-1.

\subsection{Mechanical testing of Composite sheet}

\subsubsection{Tensile Strength testing of Composite sheets}

The composite sheets are mechanically cut according to ISO 527-4 Type2 where the testing speed was $50 \mathrm{~mm} / \mathrm{min}$. Tensile stress was determined by dividing the force by the average specimen area. The tensile strength is the maximum tensile stress achieved before failure. The test is performed at $23{ }^{\circ} \mathrm{C}$ and another set of 3 samples were immersed in water for 4 hours and then measured. The results are listed in Figure 4.

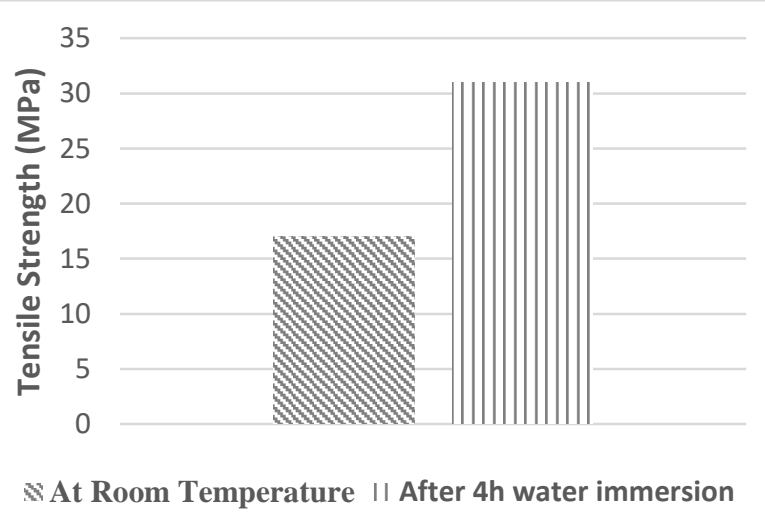

Figure 4. Tensile Strength of 50\%:50\% NF:PLA composite sheet at $23^{\circ} \mathrm{C}$ and after water immersion for 4 hours

The Tensile strength of composite at $23^{\circ} \mathrm{C}$ was $17 \mathrm{MPa}$ where after water immersion was increased to $31 \mathrm{MPa}$. The elongation at break at $23{ }^{\circ} \mathrm{C}$ was $2.3 \%$ where after water immersion the elongation increased to $5.2 \%$. Using water as treatment was acted as plasticizers to natural fibers. The cellulosic fibers are likely to swell after wetting which increases the elongation [10].

\subsubsection{Flexural Strength testing of Composite sheets}

The Flexural strength test was performed according to ISO 14125 Method A with three point set-up. The testing speed was chosen as $2 \mathrm{~mm} / \mathrm{min}$. Flexural strength as the maximum fiber stress before it cracks was measured. Flexural modulus also refers to modulus in bending is the ratio of maximum stress to maximum strain within elastic limit of stress-strain diagram. 
Araştırma

DOI: 10.34186/klujes.626590
Öztürk/Kırklareli University Journal of Engineering and Science 6-1(2020) 21-31

Geliş Tarihi:30.09.2019

Kabul Tarihi:30.06.2020

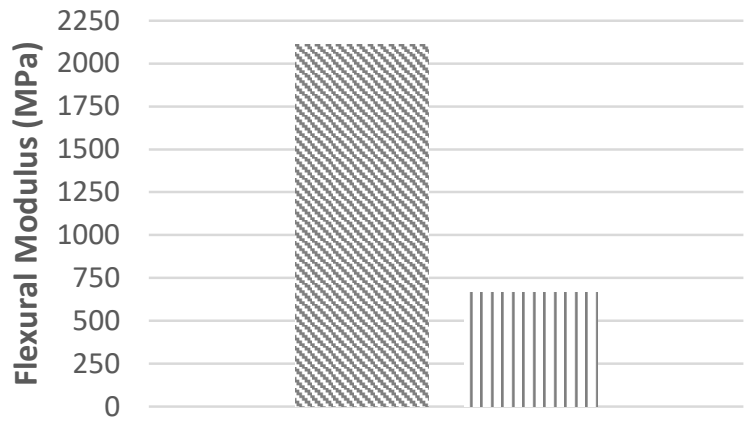

At Room Temperature II After 4h water immersion

Figure 5. Flexural Modulus of 50\%:50\% NF:PLA composite sheet at $23^{\circ} \mathrm{C}$ and after water immersion for 4 hours

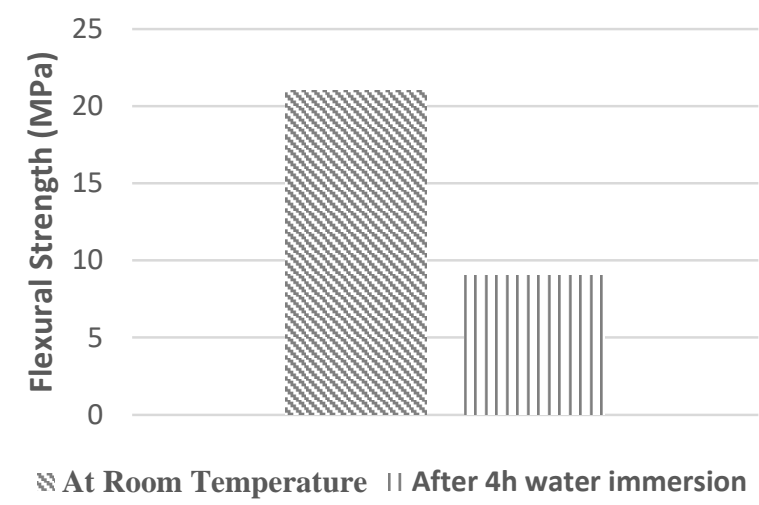

Figure 6. Flexural Strength of 50\%:50\% NF:PLA composite sheet at $23^{\circ} \mathrm{C}$ and after water immersion for 4 hours

The flexural modulus (Figure 5) and flexural strength (Figure 6) of the composite at $23{ }^{\circ} \mathrm{C}$ was $2113 \mathrm{MPa}$ and $21 \mathrm{MPa}$, respectively. The immersion of composite to water for 4 hours resulted into a decrease in the flexural modulus and flexural strength to $667 \mathrm{MPa}$ and $9 \mathrm{MPa}$, respectively.

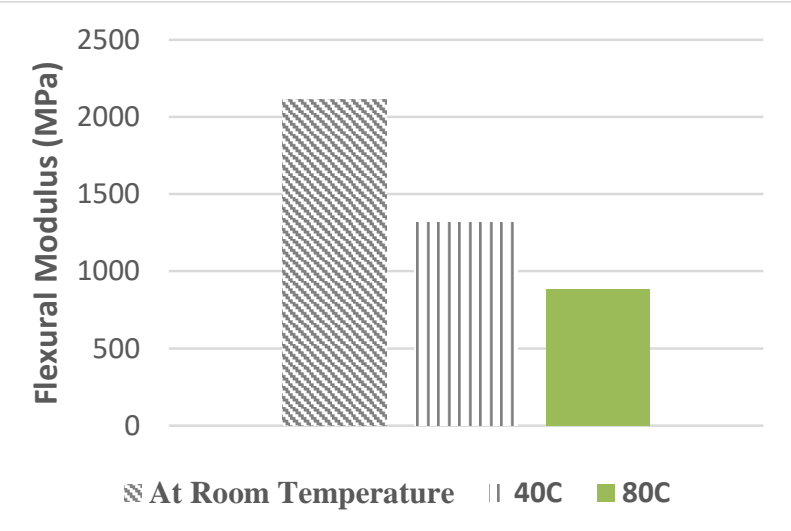

Figure 7. Flexural Modulus of 50\%:50\% NF:PLA composite sheet at $23^{\circ} \mathrm{C}, 40^{\circ} \mathrm{C}$ and $80^{\circ} \mathrm{C}$ 
Araştırma

DOI: $10.34186 /$ klujes. 626590
Öztürk/Kırklareli University Journal of Engineering and Science 6-1(2020) 21-31

Geliş Tarihi:30.09.2019

Kabul Tarihi:30.06.2020

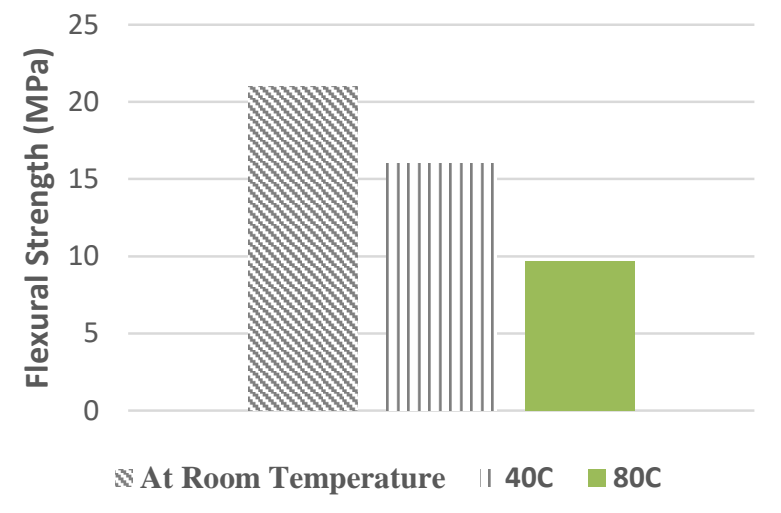

Figure 8. Flexural Strength of 50\%:50\% NF:PLA composite sheet at $23^{\circ} \mathrm{C}, 40^{\circ} \mathrm{C}$ and $80^{\circ} \mathrm{C}$

The specimen are conditioned for 2 hours in the climatic chamber unit of the universal tensile machine at $23{ }^{\circ} \mathrm{C}, 40{ }^{\circ} \mathrm{C}$ and $80{ }^{\circ} \mathrm{C}$. The flexural modulus decreases from $2113 \mathrm{MPa}$ to 1314 $\mathrm{MPa}$ and $886 \mathrm{MPa}$ when conditioned to $40^{\circ} \mathrm{C}$ and $80{ }^{\circ} \mathrm{C}$, respectively (Figure 7). The flexural strength decreased from $21 \mathrm{MPa}$ to $16 \mathrm{MPa}$ and $9.7 \mathrm{MPa}$ after conditioning at $40{ }^{\circ} \mathrm{C}$ and $80{ }^{\circ} \mathrm{C}$, respectively (Figure 8). The mechanical properties have decreased after heating which can be explained by the glass transition point observed around $63.7^{\circ} \mathrm{C}$ in DSC first heating curve.

\subsubsection{Charpy Impact testing of Composite sheets}

The charpy impact test was performed according to ISO-179-1 (Table 2). The average of $21 \mathrm{~kJ} / \mathrm{m}^{2}$ was calculated from 5 specimen.

Table 2. The Charpy impact strength results at room temperature

\begin{tabular}{|c|c|}
\hline Sample & Charpy impact $\mathrm{kJ} / \mathrm{m}^{2}$ \\
\hline 1 & 21 \\
\hline 2 & 22 \\
\hline 3 & 21 \\
\hline 4 & 21 \\
\hline 5 & 21 \\
\hline Average & 21.3 \\
\hline
\end{tabular}




\section{Araştırma}

DOI: $10.34186 /$ klujes.626590
Öztürk/Kırklareli University Journal of Engineering and Science 6-1(2020) 21-31

Geliş Tarihi:30.09.2019

The charpy impact test above $18 \mathrm{~kJ} / \mathrm{m}^{2}$ is like LyondellBasell Hostacom CR $1171 \mathrm{G}$, which is general polypropylene copolymer grade used for automotive interior trim parts.

\subsection{Stereomicroscope image of Composite Sheet}

The streomicroscope image was taken at 5X magnification (Figure 8). The wetting of the natural fiber with the PLA polymer is observed where the voids are visible. No PLA fibers was observed in the composite structure where all the polymer fiber was melted.

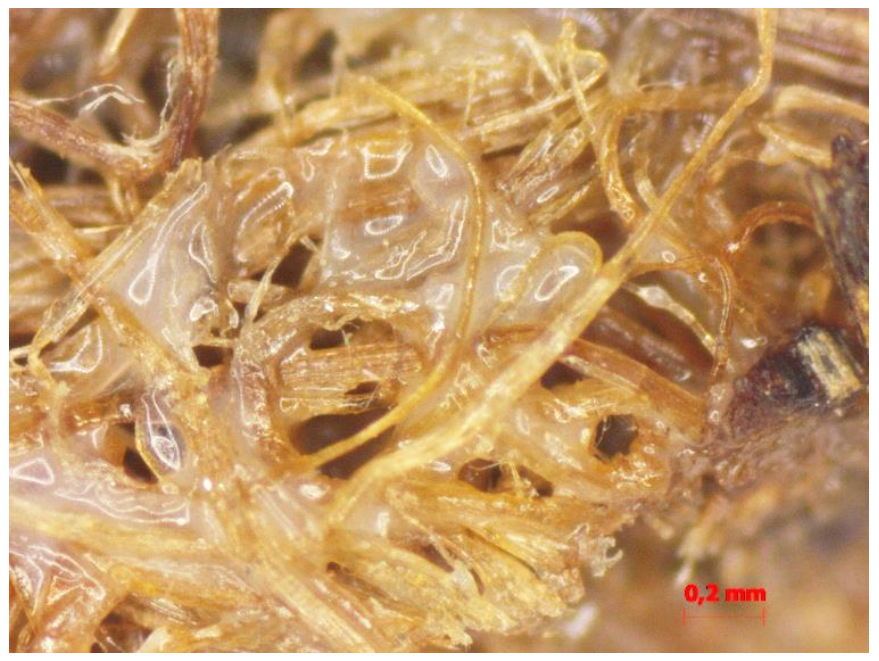

Figure 8. Streomicroscope image of NF: PLA composite

\section{CONCLUSION}

In the study, the natural fiber and PLA fiber were homogenously mixed by needle-punch method. The low density of the composite resulted into a weight reduction solution which can be processed at industrial applications. The water immersion of composite sheet results into higher tensile strength which is mainly due to swelling of the fibers which acts as surface modification through the direction of the applied force. On the other hand, the bending test is perpendicular to fiber orientations which decreases flexural strength after water immersion. The mechanical strength has dropped by conditioning the specimen at high temperature due low glass transition of PLA. The wetting of the PLA to natural fiber was observed at stereomicroscope image where air gaps were observed.

Natural fiber composites are good candidates for interior automotive applications as sustainable and eco-friendly solution with low density and high strength with treatment. The major drawback for exterior automotive application is the water absorption and low glass transition 
Araştırma

DOI: $10.34186 /$ klujes. 626590
Öztürk/Kırklareli University Journal of Engineering and Science 6-1(2020) 21-31

Geliş Tarihi:30.09.2019

Kabul Tarihi:30.06.2020

temperature. The study showed that PLA fiber can be alternatively used like PP fiber in compression moulding.

\section{ACKNOWLEDGMENTS}

This study was supported by TUBITAK project number: 3151221 ; we would like to thank Doç. Dr. Güralp Özkoç from Kocaeli University, Department of Chemical Engineering, for his support in this project.

\section{REFERENCES}

[1] Bhattacharyya, D., Bowis, M., Jayaraman, K., Thermoforming woodfibre-polypropylene composite sheets, Composites Science and Technology, Volume 63, Issue 3-4, 353-365, 2003

[2] Davey, S., Das, R., Cantwell, W.J., Kalyanasundaram, S., Forming of studies of carbon fiber composite sheets in dome forming processes, Composite Structures, 97, 310-316, 2013

[3] Zampaloni, M., et al., Kenaf natural reinforced polypropylene composites: a discussion on manufacturing problems and solutions, Composites: Part A, 38, 1569-580, 2007

[4] Hsiao, S.W., Kikuchi, N., Numerical analysis and optimal design of composite thermoforming process. Computational Methods in Applied Mechanics and Engineering, 177, 1-34, 1999

[5] Xu, J., Widyorini, R., Yamauchi, H., Kawai, S., Development of Binderless Fibreboard from Kenaf Core, Journal of Wood Science, 52, 236-243, 2006

[6] Feng, D., Caulfield, D.F., Sanadi, A.D., Effect of compatibilizer on the structure property relationships of kenaf-fiber/polypropylene composites, Polymer Composites, 22, 506-517, 2001

[7] Mohanty, A.K., Drzal, L.T., Misra, M., Engineered reinforced polypropylene composites: influence of surface modifications and novel powder impregnation processing, Journal of Adhesion Science and Technology, 16, 999-1015, 2002

[8] Auran Efendy, M.G., Pickering, K.L., Fibre orientation of novel dynamically sheet formed discontinuous natulra fibre PLA composites, Composites: Part A, 90, 82-89, 2016

[9] Oksman, K., Skrifvars, M., Selin, J.F., Natural fibres as reinforcement in polylactic acid (PLA) composites, Composites Science and Technology, 63, 1317-1324, 2003 
Araştırma

DOI: $10.34186 /$ klujes. 626590
Öztürk/Kırklareli University Journal of Engineering and Science 6-1(2020) 21-31

Geliş Tarihi:30.09.2019

[10] Wang, W., Lowe, A., Kalyanasundaram, S., Effect of Chemical Treatments on Flax Fibre Reinforced Polypropylene Composites on Tensile and Dome Forming Behaviour, International Journal of Molecular Science, 16, 6202-6216, 2015 